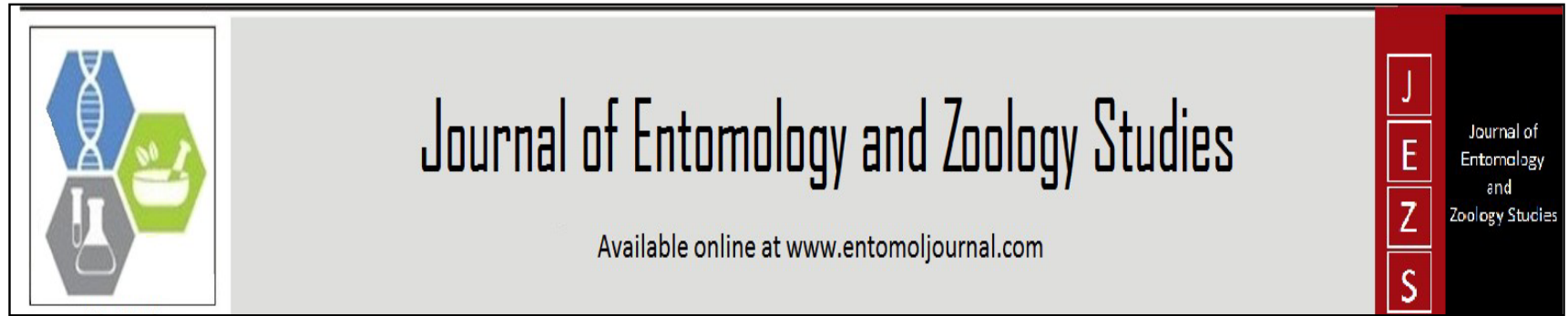

E-ISSN: 2320-7078 P-ISSN: 2349-6800 JEZS 2016; 4(6): 623-625

(C) 2016 JEZS

Received: 23-09-2016

Accepted: 24-10-2016

Mark Ian Cooper

Department of Biologica

Sciences, University of Cape

Town, Private Bag, Rondebosch

7701, Republic of South Africa
Correspondence

Mark Ian Cooper

Department of Biological

Sciences, University of Cape

Town, Private Bag, Rondebosch

7701, Republic of South Africa

\section{Do females control the duration of copulation in the aposematic millipede Centrobolus inscriptus?}

\section{Mark Ian Cooper}

\section{Abstract}

Studies on the sexually dimorphic aposematic millipede Centrobolus inscriptus are providing new insight into mating behaviour and ecology of arthropods. The previous studies on control of mate-guarding in the spirostreptid millipede Doratogonus (=Alloporus) uncinatus proved males control the duration of copulation. Here we review 18 studies on Centrobolus inscriptus and test the null hypothesis: females do not control the duration of copulation. In all the studies of Centrobolus there is no evidence for male control of copulation duration but female control. By protracting the time spent with each male females mediate sperm competition and contracts the re-mating interval which is known to affect sperm competition which ultimately affects paternity.

Keywords: Centrobolus inscriptus, diplopoda, myriapoda, collobognatha, Spirobolida, millipede, mating

\section{Introduction}

Recent studies on the sexually dimorphic aposematic millipede Centrobolus inscriptus are providing new insight into mating behaviour and ecology of arthropods ${ }^{[1-18]}$. The previous studies on control of mate-guarding in the spirostreptid millipede Doratogonus (=Alloporus) uncinatus proved males control the duration of copulation ${ }^{[19]}$. Here we review studies on Centrobolus inscriptus and test the null hypothesis: females do not control the duration of copulation. All evidence suggests females control the duration of copulation in C. inscriptus.

\section{Materials and Methods}

The literature was searched for all recent studies using appropriate keywords Centrobolus inscriptus, diplopoda, myriapoda, collobognatha, Spirobolida, millipede, mating. The authors own publication collection was consulted thereafter. Centrobolus millipedes were collected from their typical habitat in Afromontane coastal forest. A subset of four species were chosen for comparative purposes because they could be easily collected in large numbers and identified by their distinct genital morphology. C. ruber is the southernmost of these four species, and therefore also the least tropical; Port Shepstone $\left(30^{\circ} 42^{\prime} \mathrm{S}, 30^{\circ} 27^{\prime} \mathrm{E}\right)$. C. inscriptus and $C$. anulatus are latitudinal intermediates with sympatric distributions; Mtunzini $\left(28^{\circ} 51^{\prime} \mathrm{S}, 31\right.$ o $\left.46^{\prime} \mathrm{E}\right)$. C. fulgidus is the northernmost, a subtropical species; St Lucia $\left(28^{\circ} 23^{\prime}\right.$ $\left.\mathrm{S}, 32^{\circ} 25^{\prime} \mathrm{E}\right)$. The majority of observations were made during the summer rainy seasons of 1995-1997, 2004, and 2007/2008.

Millipede copulatory events form a continuous sequence and because copula pairs rather than precopulatory behaviours are mostly encountered in the field, it was decided to collect large sample sizes and return to the laboratory to reconstruct the full behavioral sequences from continuous observations. Copulation movements were video recorded in a close-up position using a standard VHS camera to provide detailed descriptions of any copulatory courtship. Behaviour patterns were identified by repeatedly freeze-framing the footage. Positions in copula were categorized as being either in parallel or coiled. Simple descriptive statistics were used to seek covariation around copulation duration. Movements produced by the males in copula were also described.

\section{Results}

The copulations in C. inscriptus are highly prolonged and coiled (Figures $1 \& 2$ ) compared to parallel copulations of $C$. ruber (Figure 2). Behavioural sequence rapprochement or pair formation involves (a) members of both sexes becoming highly surface active and "swarming" as a result of external stimuli brought about by single showers of rain, (b) a quicker response 
in males moving at approximately 1.5 times faster. (1.6crnlsec, $n=10$ ) than the females suggesting them to be the searching sex. This was more so the case for $C$. inscriptus with surface activity shifting from the forest floor vertically upwards into the trees and shrubs (c) females possibly producing long range pheremonal and close range cutaneous attractants. After finding a mate the mounting stage involves the male running up the back of the female and clinging to her aided by the tarsal pads on the legs [13]. Relatively long precopulatory periods, up to 10 minutes, would ensue if the female conglobated (recoiling in the same manner as that in response to attack from predators) before the male could obtain access (Figure $1 \mathrm{~A}$ ). A male would often attempt to reduce the female resistance by attempting to uncoil her using the labrum (mouthparts), first three pairs of legs, and semieverted gonopods. The female's reluctance to mate sometimes involved the withdrawal and eversion of the vulvae. Physical coupling is a multistage process. It seems to be a matter of time before the male uncoils the female and when the male has succeeded in unrolling the female, the two sexes align and make ventro-ventro contact. The ventral surfaces of both are contiguous with ring seven of the male opposite ring three of the female (Figure $1 \mathrm{~B}$ ). The head of the female is held in a fixed position by the first three pairs of the males legs. The gonopods evert and the female vulvae, opening on segments two/three are pulled out by the male coleopods on ring seven confirming the speculated function of the coleopods ${ }^{[9]}$.

The shortest copulation durations were recorded for species appear to show less vigorous copulation; as is the case in other juliform millipedes where differences in the duration of copulation are thought to reflect the intensity of sperm competition between species - prolonged copulation is a form of mate guarding whereby the male attempts to assure paternity by controlling the duration of copulation. However, there is a case for female control of copulation durations since copulation durations were significantly positively correlated with female size and sexual size dimorphism but not male size [20].
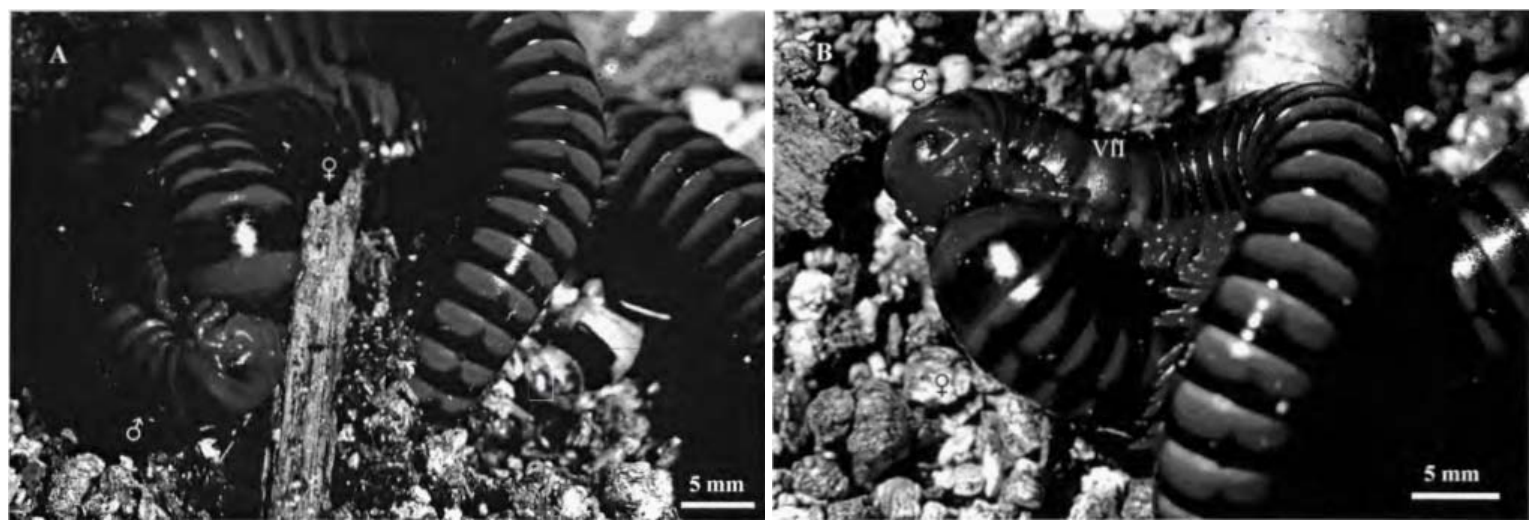

Fig 1: The initial stages in the mating sequence of the millipede Centrobolus inscriptus. A. The precopulatory struggle begins with the female denying the male access by conglobating (coiling up) but soon results in the male uncoiling the female; B. The male, with the trunk turned around the female, is in the process of everting the gonopods on the seventh (VII) diplosegment.
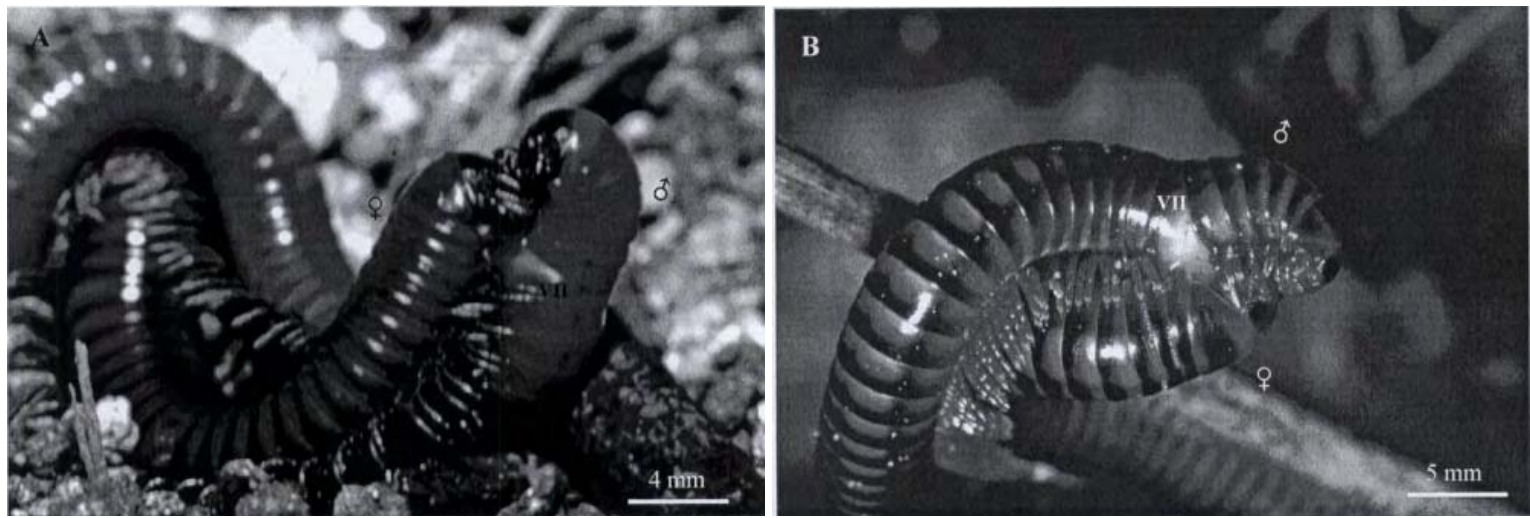

Fig 2: The copulatory positions of two millipede species differing in the extent to which the gonopods are everted and enter the female vulvae:

A. Centrobolus ruber showing that the gonopods are shallow-seated; B. C. inscriptus gonopods are completely everted and deap-seated with the resultant production of the sexual 'collar' that is typified by hydropneumatic movements associated with bouts of sperm transfer and

displacement. The membranes of the gonopod-bearing seventh (VII) diplosegment evert and inflate to form a sexual collar.

Evidence exists for absence of male control and presence of female control of copulation duration in C. inscriptus ${ }^{[20]}$. In the absence of a preference there is size-assortative mating ${ }^{[6]}$. SSD correlates positively with copulation duration. This suggests either a conflict of interests over copulation duration or size-based control. Since $C$. inscriptus has relatively small females and large males ${ }^{[18]}$ it would appear males have control. Cross-mating experiments between C. inscriptus X C. annulatus indicate size-based female control ${ }^{[6]}$.

\section{Discussion}

Evidence appears to exist for both male and female control in Centrobolus. When species specific patterns are analysed the most studied example, $C$. inscriptus, shows under natural predation copulations are long and perhaps even costly for males [17]. In all the studies of Centrobolus we found no evidence for male control but prolonged copulations under female control. Females are thought to protract the time spent with each male and hence mediate sperm competition. This 
also contracts the re-mating interval which is known to affect sperm competition and ultimately decides paternity ${ }^{[3]}$.

\section{Conclusion}

There is no evidence for male control of copulation duration in Centrobolus. Evidence from the literature suggests female control of copulation duration in $C$. inscriptus.

\section{References}

1. Cooper MI. Sex ratios, mating frequencies and relative abundance of sympatric millipedes in the genus Chersastus (Diplopoda, Pachybolidae). Arthropods. 2014; 3(4):174-176.

2. Cooper MI. Sexual size dimorphism and corroboration of Rensch's rule in Chersastus millipedes (Diplopoda, Pachybolidae). Journal of Entomology and Zoology Studies. 2014b; 2014; 2(6):264-266.

3. Cooper MI. Competition affected by re-mating interval in a myriapod. Journal of Entomology and Zoology Studies. 2015; 3(4):77-78.

4. Cooper MI. Elaborate gonopods in the myriapod genus Chersastus (Diplopoda, Trigoniulidae). Journal of Entomology and Zoology Studies. 2015; 3(4):235-238.

5. Cooper MI. Sperm storage in Centrobolus spp. and observational evidence for egg simulation. Journal of Entomology and Zoology Studies. 2016; 4(1):127-129.

6. Cooper MI. Fire millipedes obey the female sooner norm in cross mating Centrobolus (Myriapoda). Journal of Entomology and Zoology Studies. 2016; 4(1):173-174.

7. Cooper MI. Symmetry in ejaculate volumes of Centrobolus inscriptus Attems (Spiroboloidea, Trigoniulidae). Journal of Entomology and Zoology Studies. 2016; 4(1):386-387.

8. Cooper MI. Instantaneous insemination in the millipede Centrobolus inscriptus (Spirobolida, Trigoniulidae) determined by artificially-terminated mating. Journal of Entomology and Zoology Studies. 2016; 4(1):487-490.

9. Cooper MI. Gonopod mechanics in Centrobolus Cook (Spirobolida, Trigoniulidae) II. Images. Journal of Entomology and Zoology Studies. 2016; 4(2):152-154.

10. Cooper MI. Post-insemination associations between males and females in Diplopoda: A remark on Alcock's (1994) predictions of the mate-guarding hypothesis. Journal of Entomology and Zoology Studies. 2016; 4(2):283-285.

11. Cooper MI. Heavier-shorter-wider females in the millipede Centrobolus inscriptus Attems (Spirobolida, Trigoniulidae). Journal of Entomology and Zoology Studies. 2016; 4(2):509-510.

12. Cooper MI. Sexual bimaturism in the millipede Centrobolus inscriptus Attems (Spirobolida, Trigoniulidae Journal of Entomology and Zoology Studies. 2016; 4(3):86-87.

13. Cooper MI. Tarsal pads of Centrobolus Cook (Spiroboloidea, Trigoniulidae). Journal of Entomology and Zoology Studies. 2016; 4(3):385-386.

14. Cooper MI. Confirmation of four species of Centrobolus Cook (Spirobolida: Trigoniulidae) based on gonopod ultrastructure. Journal of Entomology and Zoology Studies. 2016; 4(4):389-391.

15. Cooper MI. Sperm storage in Centrobolus inscriptus Attems (Spirobolida: Trigoniulidae). Journal of Entomology and Zoology Studies. 2016; 4(4):392-393.

16. Cooper MI. Sperm dumping in Centrobolus inscriptus Attems (Spirobolida: Trigoniulidae). Journal of
Entomology and Zoology Studies. 2016; 4(4):394-395.

17. Cooper MI. Syncopulatory mate-guarding affected by predation in the aposematic millipede Centrobolus inscriptus in a swamp forest. Journal of Entomology and Zoology Studies. 2016; 4(6):483-484.

18. Cooper MI. The relative sexual size dimorphism of Centrobolus inscriptus compared to 18 congenerics. Journal of Entomology and Zoology Studies. 2016; 4(6):504-505.

19. Telford SR, Dangerfield JM. Males control the duration of copulation in the tropical millipede Alloporus uncinatus (Diplopoda: Julida), South African Journal of Zoology. 1994; 29(4):266-268. doi: 10.1080/02541858.1994.11448362.

20. Cooper MI, Telford SR. Copulatory Sequences and Sexual Struggles in Millipedes. Journal of Insect Behaviour. 2000; 13(2):217-230. doi: 10.1023/A:1007736214299. 